\title{
A survey of pharmacists' perception of foundation level competencies in African countries
}

\author{
Arit Udoh ${ }^{1}$, Andreia Bruno ${ }^{2}$ and lan Bates ${ }^{1 *}$ (D)
}

\begin{abstract}
Background: Evidence from published literature in pharmacy practice research demonstrate that the use of competency frameworks alongside standards of practice facilitate improvement in professional performance and aid expertise development. The aim of this study was to evaluate pharmacists' perception of relevance to practice of the competencies and behaviours contained in the FIP Global Competency Framework (GbCF v1). The overall objective of the study was to assess the validity of the GbCF v1 framework in selected countries in Africa.

Methods: A cross-sectional survey of pharmacists practicing in 14 countries in Africa was conducted between November 2012 and December 2014. A combination of purposive and snowball sampling method was used. Data was analysed using SPSS V22.

Results: A total of 469 pharmacists completed the survey questionnaire. The majority (91\%) of the respondents were from four countries: Ghana, Kenya, Nigeria and South Africa. The study results showed broad agreement on relevance to practice for $90 \%$ of the behaviours contained in the GbCF v1 framework. Observed disagreement was associated with area of pharmacy practice and the corresponding patient facing involvement $(p \leq 0.05)$. In general, the competencies within the 'pharmaceutical care' and 'pharmaceutical public health' clusters received higher weighting on relevance compared to the research-related competencies which had the lowest. Specific inter-country variability on weighting of relevance was observed in five behaviours in the framework although, this was due to disparity in 'degree of relevance' that was related to sample composition in the respective countries.

Conclusion: The competencies contained in the GbCF v1 are relevant to pharmacy practice in the study population; however, there are some emergent differences between the African countries surveyed. Overall, the findings provide preliminary evidence that was previously lacking on the relevance of the GbCF v1 competencies to pharmacy practice in the countries surveyed.
\end{abstract}

Keywords: Competencies, Professional development, Pharmacy practice, Pharmacy workforce

\section{Background}

Competent pharmacists improve therapeutic outcomes, minimise the risk associated with medicines use and assure patient safety through the provision of medicine expertise [1-5]. The central role pharmacists play within the health system underpins the demand for a competent and highly skilled workforce that is equipped with the requisite knowledge and skills relevant to population health needs [6-8]. This is of particular importance in resource-limited settings

\footnotetext{
* Correspondence: i.bates@ucl.ac.uk

${ }^{1}$ University College London School of Pharmacy, London, United Kingdom

Full list of author information is available at the end of the article
}

such as in sub-Saharan Africa where severe workforce shortages hamper access to health services including medicines expertise $[9,10]$.

The International Pharmaceutical Federation (FIP) is the global leadership body representing 3 million pharmacists and pharmaceutical scientists worldwide [11]. FIPEd, which is the pharmacy education and workforce development arm of the FIP, advocates the need to define and articulate the competencies that pharmacists require to consistently perform safely, effectively, and efficiently [12]. The overall objective is to provide an infrastructure for global guidance 
on the practice-based expectations of the pharmacy workforce [13].

Published research demonstrate that when competency frameworks are used alongside standards of practice: it facilitates improvement of pharmacists' performance [14-17], promotes the attainment and maintenance of fitness to practice [17, 18], aids identification of knowledge gaps and learning needs [19], and fosters continuing professional development [20]. The findings of longitudinal studies show that using competency frameworks to identify knowledge gaps and tailor learning activities significantly improve pharmacists' performance $(p \leq 0.05)$ at 6 months $[14,15,17], 9$ months [16], and 12 months [18, 20]. Similar findings from comparative studies conducted in United Kingdom [14, 20] indicate that competency frameworks facilitate a more sustained improvement in pharmacists' performance $(p<0.001)$ in the intervention group at 12 months when compared to a control group that had no access to a framework. These findings have also been corroborated by other studies in Australia [15], Croatia [18], Serbia [17], and Singapore [16].

In 2012, FIPEd developed the FIP Global Competency Framework (GbCF v1) using evidence-based methodologies [21]. This framework was specifically designed to serve as a source document containing the core competencies expected of foundation level pharmacy practitioners (this means, pharmacists with less than 5 years practice experience) [13]. Since its development, the GbCF v1 has been successfully used to design pre-service education and training curriculum in a number of countries [22,23]. It has also been used to develop country-specific frameworks for inservice practitioners in Ireland [24], the Pacific Island countries [25], Croatia, Singapore and Serbia [21]. A previous survey that validated the GbCF v1 using evidence from 64 countries [26] showed that $70 \%$ of respondents ranked all the behaviours in the questionnaire as relevant to practice. However, respondents from countries in Africa comprised only $12.3 \%$ of the total sample in the survey [26]. The aim of this present study was therefore to evaluate pharmacists' perception of the relevance to practice of the competencies and behaviours contained in the GbCF v1, focusing on selected African countries.

\section{Methods}

\section{Data collection and sampling}

A cross-sectional survey of pharmacists practicing in selected countries in Africa was conducted between November 2012 and December 2014. A combination of purposive and snowball sampling method was used. Due to a lack of access to the pharmacy membership list of the respective countries in Africa, the URL link to the online survey was circulated centrally via email to the 35 FIP member organisations in Africa for onward distribution to their respective individual members. The FIP member organisations contacted were the leadership bodies representing practicing pharmacists in
24 countries in Africa (list provided in the Appendix). These organisations were selected based on availability of contact persons, expression of interest to participate when contacted and willingness to gather data. The survey invite was also disseminated through the FIP United Nations Education Scientific and Cultural Organisation (UNESCO) University Twining Network (FIP UNESCO UNITWIN) in Africa. The survey URL link was further customised and distributed via social media and short message service platforms including Facebook $^{\circ}$, Twitter ${ }^{\circ}$, WhatsApp ${ }^{\circ}$ and Blackberry Messenger ${ }^{\circ}$. Respondents were encouraged to assist by forwarding the survey URL link to their colleagues and contacts. Email reminders were thereafter forwarded monthly through the aforementioned media until the end of the study. Due to the non-availability of reliable estimates on the number of pharmacists per country organisation represented in FIP, a sampling frame was not feasible and survey respondents were therefore recruited consecutively until the end of the study period.

\section{Survey questionnaire}

An anonymous online questionnaire developed and validated in a previous study [26] was used. The questionnaire was fully reproduced from the GbCF v1 and comprised of 105 questions. Five questions related to demographic information while the remaining questions referred to the 100 GbCF v1 behavioural statements (labelled B1 through B100, and hereafter referred to as 'behaviours'). These behaviours are grouped under the 20 competency domains and four broad competency clusters in the framework (Table 1).

\section{Data analysis}

Survey data was collected electronically, without transformation and analysed using the Statistical Package for the Social Sciences (SPSS) version 22. To ensure data quality, a random $10 \%$ of the total survey sample was reviewed for coding errors with missing values replaced with code 999. Respondents' perception of relevance to practice of each of the behaviours was evaluated using a 4-point Likert scale. Respondents were required to rank each of the $100 \mathrm{GbCF}$ v1 behaviours as 'not relevant', of 'low relevance,' relevant' or 'highly relevant' to their practice. For the purpose of analysis and to ensure the results produced could be meaningfully interpreted, the response categories in the Likert scale were further aggregated. The 'highly relevant' and 'relevant' ratings were condensed into one category: 'relevant', while the 'low relevance' and 'not relevant' ratings remained distinct categories. Agreement was evaluated by comparing the proportion (frequency and percentage) of the total ratings in the three categories. Consensus on relevance to practice was attained when not more than $10 \%$ of the respondents ranked a given behaviour as 'not relevant'. This threshold was defined empirically based on previous research involving pharmacists from 64 countries [26]. 
Table 1 Components of the GbCF v1 framework

\begin{tabular}{ll}
\hline Cluster & Composition and description \\
\hline Pharmaceutical public health & $\begin{array}{l}\text { Four behaviours labelled B1-B4 grouped under two competencies: } \\
\text { 'health promotion' and 'medicines information and advice' }\end{array}$ \\
Pharmaceutical care & 25 behaviours labelled B5-B29 grouped under six competencies: 'assessment of medicines', \\
& 'dispensing', 'medicines', 'monitor medicines therapy', 'patient consultation and diagnosis' \\
Organisation and management & 32 behaviours labelled B30-B61 grouped under six competencies: 'budget and reimbursement', \\
& 'human resource management', 'improvement of service', 'procurement', 'supply chain and \\
management', and 'work place management' & 39 behaviours labelled B62-B100 grouped under six competencies: 'communication skills', \\
Professional and personal & 'continuing professional education', 'legal and regulatory practice', 'professional and ethical \\
& practice,', 'quality assurance and research in the workplace', 'self-management'
\end{tabular}

Pearson's chi-square $\left(\chi^{2}\right)$ test was used to assess homogeneity in the survey sample. The test of homogeneity was undertaken to ascertain whether the sample could be treated as a group irrespective of the number of replies received per country. The $x^{2}$ test was also used to evaluate the relationship between weighting of relevance and area of practice for behaviours that showed a lack of consensus. In order to assess inter-country variability in responses, multivariate analysis of variance (MANOVA) via Pillia's trace test $(V)$ was used to evaluate weighting of relevance per country per competency with confirmatory post hoc analysis conducted using Bonferroni correction.

\section{Ethical consideration}

Formal ethical approval from the research ethics committee was not required for this study as it did not involve the use of identifiable patient information or data, rather the study recruited pharmacists and sought their views by virtue of their professional roles. However, consent to participate was sought from the respondents prior to completing the survey questionnaire. Participation was voluntary, and confidentiality was maintained at all times with responses remaining anonymous. All data collected in the research were stored in an encrypted database with hard copies kept in locked filling cabinets at the Department of Practice and
Policy, UCL School of Pharmacy, United Kingdom. Access to study data was restricted to the three researchers directly involved with the study.

\section{Results}

\section{Demography}

Four hundred and sixty-nine pharmacists from 14 countries in Africa responded to the survey. Over half of the survey respondents were female (54\%). The mean length of practice was 7.7 years ( $\mathrm{SD} \pm 8.1$ years; min-max $1-43$ years). Respondents with less than 5 years practice experience made up $47 \%$ of the sample while pre-registration candidates/ pharmacy students in their last year (internship) comprised $5.5 \%$. The majority of the respondents were in hospital practice (56.7\%). Table 2 shows the summary of the distribution of survey replies per country and area of pharmacy practice.

\section{Sample homogeneity}

Four countries-Kenya, Nigeria, South Africa and Ghanaeach had more than 50 replies and made up $91 \%$ of the sample. Ten countries-Ethiopia, Egypt, Lesotho, Uganda, Tunisia, Namibia, Sudan, Tanzania, Zambia and Zimbabwehad fewer than 20 survey replies each. The observed disparity in number of replies indicated two cluster groups: a 'high response group' made up of countries with more than 50

Table 2 Survey replies per country per area of pharmacy practice

\begin{tabular}{|c|c|c|c|c|c|}
\hline \multirow[t]{2}{*}{ Area of practice } & \multicolumn{5}{|c|}{ Country N (\%) } \\
\hline & Kenya & Ghana & Nigeria & South Africa & Others $^{a}$ \\
\hline Academic pharmacy & $1(1.0)$ & $4(4.3)$ & $11(6.6)$ & $21(32.8)$ & $6(14.0)$ \\
\hline Administrative pharmacy & $6(5.8)$ & $13(14.0)$ & $4(2.4)$ & $2(3.1)$ & $4(9.3)$ \\
\hline Community pharmacy & $2(1.9)$ & $10(10.8)$ & $41(24.7)$ & $10(15.6)$ & $10(23.3)$ \\
\hline Hospital pharmacy & $89(86.4)$ & $60(64.5)$ & $80(48.2)$ & $23(35.9)$ & $14(32.6)$ \\
\hline Industrial pharmacy & $1(1.0)$ & $3(3.2)$ & $26(15.7)$ & $6(9.4)$ & $5(11.6)$ \\
\hline Others $^{b}$ & $4(3.9)$ & $3(3.2)$ & $4(2.4)$ & $2(3.1)$ & $4(9.3)$ \\
\hline Total sample & $103(22)$ & 93 (19.8) & $166(35.4)$ & 64 (13.6) & $43(9.2)$ \\
\hline
\end{tabular}

${ }^{a}$ Countries with fewer than 50 replies each [includes Zambia [15], Egypt [8], Zimbabwe [5], Uganda [3], Lesotho [3], Tunisia [5], Namibia, Ethiopia Sudan and Tanzania (1 each)]

${ }^{\mathrm{b}}$ Areas of pharmacy practice with fewer than 20 replies [includes pharmacy information [11], military and emergency [2] and laboratory and medicines control pharmacy [4]] 
Table 3 Distribution of survey replies per competency cluster per country response group

\begin{tabular}{llll}
\hline Competency cluster & Behaviour label & Country response group $(N)^{\text {a }}$ & \\
\cline { 3 - 4 } & & Countries with high response ${ }^{b}$ & Countries with low response $^{c}$ \\
\hline Pharmaceutical public health & B1-B4 & 426 & 43 \\
Pharmaceutical care & B5-B29 & 350 & 36 \\
Organisation and management & B30-B61 & 295 & 33 \\
Professional and personal & B62-B100 & 273 & 32 \\
\hline
\end{tabular}

${ }^{a}$ Countries with more than 50 replies each were regrouped as the high response group while countries with fewer than this were the low response group

Includes Ghana, Kenya, Nigeria and South Africa

Includes Zambia, Egypt, Zimbabwe, Uganda, Lesotho, Tunisia, Namibia, Ethiopia Sudan and Tanzania

replies each, and a 'low response group' made up of countries with fewer than 20 replies each. The number of replies also varied for the four competency clusters in the framework. Table 3 shows a summary of the distribution of replies for each competency cluster per country group.

The test for homogeneity in the survey sample showed that distribution of the ratings in the response categories (that is, in the 'relevant,' 'low relevance' and 'not relevant' categories) was strongly associated with the country group for 11 behaviours $[(p<0.01)$; Table 4]. These 11 behaviours were distributed across the four competency clusters in no observable pattern. The outcome of the $\chi^{2}$ test implied homogeneity in responses between the country groups for $89 \%$ of the GbCF v1 behaviours. The low counts (frequency of less than 5) observed in the table cells within the group with low number of replies $(N<20$ per country; Table 4$)$ suggested an absence of data in this group rather than disparity in responses between countries. Given the $x^{2}$ test known property of being imprecise in 'small' samples [27-29], it is likely that the test overestimated the relationship between the responses and the country group. Based on this, sample homogeneity was assumed and the survey replies were subsequently analysed as a group. Figure 1 shows the percentage of ratings in the 'relevant' category for the low response, high response, and

Table 4 Behaviours showing association with country response group

\begin{tabular}{|c|c|c|c|c|c|c|c|c|c|c|}
\hline \multirow[t]{2}{*}{ Cluster } & \multirow[t]{2}{*}{ Competency } & \multirow[t]{2}{*}{ Behaviour } & \multicolumn{3}{|c|}{ High response countries $(N)$} & \multicolumn{3}{|c|}{ Low response countries $(N)$} & \multirow{2}{*}{$\begin{array}{l}x^{2} \\
\text { value }\end{array}$} & \multirow[t]{2}{*}{$p$} \\
\hline & & & $\begin{array}{l}\text { Not } \\
\text { relevant }\end{array}$ & $\begin{array}{l}\text { Low } \\
\text { relevance }\end{array}$ & Relevant & $\begin{array}{l}\text { Not } \\
\text { relevant }\end{array}$ & $\begin{array}{l}\text { Low } \\
\text { relevance }\end{array}$ & Relevant & & \\
\hline \multirow[t]{2}{*}{$\begin{array}{l}\text { Pharmaceutical } \\
\text { public health }\end{array}$} & $\begin{array}{l}\text { Health } \\
\text { promotion }\end{array}$ & [B1] Assess primary healthcare needs & 10 & 20 & 396 & $1^{*}$ & 7 & 35 & 9.67 & 0.01 \\
\hline & $\begin{array}{l}\text { Medicines } \\
\text { information } \\
\text { and advice }\end{array}$ & $\begin{array}{l}\text { [B4] Identify sources, retrieve, evaluate, } \\
\text { assess and disseminate relevant } \\
\text { medicines information according to } \\
\text { patients needs }\end{array}$ & $2^{*}$ & 22 & 402 & $1^{*}$ & 8 & 34 & 1.12 & 0.01 \\
\hline \multirow[t]{3}{*}{$\begin{array}{l}\text { Pharmaceutical } \\
\text { care }\end{array}$} & $\begin{array}{l}\text { Assessment } \\
\text { of medicines }\end{array}$ & $\begin{array}{l}\text { [B6] Identify and act upon medicines } \\
\text { interactions }\end{array}$ & 40 & 68 & 242 & $3^{*}$ & 15 & 18 & 9.56 & 0.01 \\
\hline & Dispensing & [B12] Dispense devices (e.g. inhalers) & 11 & 18 & 321 & $0^{*}$ & 9 & 27 & 20.54 & $<0.001$ \\
\hline & Medicines & $\begin{array}{l}\text { [B19] Ensure appropriate medicine } \\
\text { route, dose, time, form and response } \\
\text { for individual patients }\end{array}$ & 22 & 21 & 307 & 5 & 7 & 24 & 12.52 & 0.002 \\
\hline \multirow[t]{5}{*}{$\begin{array}{l}\text { Organisation } \\
\text { and } \\
\text { management }\end{array}$} & $\begin{array}{l}\text { Human } \\
\text { resource } \\
\text { management }\end{array}$ & $\begin{array}{l}\text { [B37] Participate and collaborate, } \\
\text { advice in therapeutic decision-making } \\
\text { and use appropriate decision referral } \\
\text { in a multi-disciplinary team }\end{array}$ & 11 & 23 & 261 & $4^{*}$ & 6 & 23 & 9.4 & 0.01 \\
\hline & $\begin{array}{l}\text { Improvement } \\
\text { of service }\end{array}$ & $\begin{array}{l}\text { [B42] Resolve, follow-up and prevent } \\
\text { medicines related problems }\end{array}$ & 10 & 23 & 262 & $1^{*}$ & 9 & 23 & 12.8 & $<0.001$ \\
\hline & Procurement & $\begin{array}{l}\text { [B44] Develop and implement a } \\
\text { contingency plan for shortages }\end{array}$ & 11 & 27 & 257 & 5 & $2^{*}$ & 26 & 8.5 & 0.01 \\
\hline & $\begin{array}{l}\text { Supply chain } \\
\text { management }\end{array}$ & $\begin{array}{l}\text { [B54] Implement system for } \\
\text { documentation and record keeping }\end{array}$ & 11 & 13 & 271 & $3^{*}$ & 8 & 22 & 22.35 & 0.001 \\
\hline & $\begin{array}{l}\text { Work place } \\
\text { management }\end{array}$ & $\begin{array}{l}\text { [B61] Recognise and manage } \\
\text { pharmacy resources (e.g. financial, } \\
\text { infrastructure) }\end{array}$ & 9 & 26 & 260 & 5 & $3^{*}$ & 25 & 10.71 & 0.01 \\
\hline $\begin{array}{l}\text { Professional } \\
\text { and personal }\end{array}$ & $\begin{array}{l}\text { Quality } \\
\text { assurance and } \\
\text { research in the } \\
\text { workplace }\end{array}$ & $\begin{array}{l}\text { [B94] Implement, conduct and } \\
\text { maintain a report system of } \\
\text { pharmacovigilance (e.g. report } \\
\text { adverse drug reactions) }\end{array}$ & 16 & 11 & 246 & $2^{*}$ & 6 & 24 & 11.88 & 0.003 \\
\hline
\end{tabular}




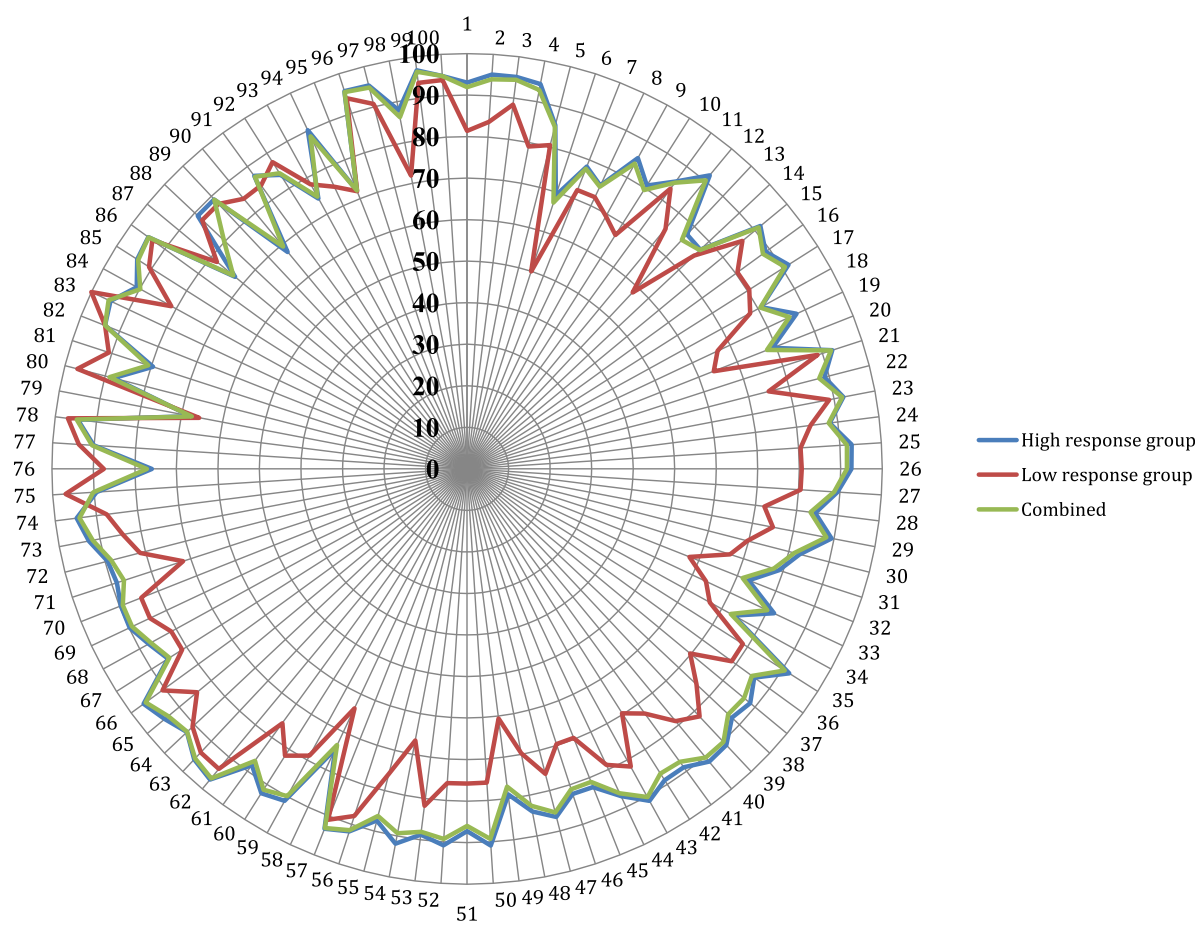

Fig. 1 Percentage of total ratings in the 'relevant' category per behaviour (not inclusive of ratings in the 'low relevance' and 'not relevant' categories). Numbers on the circumference refer to behaviour labels (1 through 100) while numbers on the vertical axis refer to percentage of total ratings

combined group of countries, respectively. The total ratings in the combined country groups indicate that at least $70 \%$ of survey respondents ranked all the behaviours in the framework as 'relevant'. This was not inclusive of the 'not relevant' and 'low relevant' ratings.

\section{Overall perception of relevance}

Consensus on relevance to practice $(N$ 'not relevant' < 10\%) was obtained for 90 behaviours in the questionnaire. This included all the behaviours in the 'pharmaceutical public health' cluster, $84 \%$ in the 'pharmaceutical care', $90 \%$ in 'organisation and management' and $92 \%$ in the 'professional and personal' cluster, respectively (please see Tables 5, 6, 7 and 8 ). The 10 behaviours with more than $10 \%$ of the total ratings in the 'not relevant' category, suggested disagreement on relevance to practice (Table 9). This observed disagreement was associated with area of pharmacy practice for six of the 'disagreed' behaviours (Table 9; $P<0.05$ ).

Table 5 Overall rating of behaviours within the pharmaceutical public health cluster

\begin{tabular}{|c|c|c|c|c|c|c|c|}
\hline \multirow[t]{2}{*}{ Pharmaceutical public health competencies $(n=469)$} & \multicolumn{2}{|c|}{ Not relevant } & \multicolumn{2}{|c|}{ Low relevance } & \multicolumn{2}{|c|}{ Relevant } & \multirow[t]{2}{*}{ Group } \\
\hline & Count & $\begin{array}{l}\text { Row } \\
\text { (N\%) }\end{array}$ & Count & $\begin{array}{l}\text { Row } \\
\text { (N\%) }\end{array}$ & Count & $\begin{array}{l}\text { Row } \\
\text { (N\%) }\end{array}$ & \\
\hline \multicolumn{8}{|l|}{ Health promotion } \\
\hline $\begin{array}{l}\text { B1. HP | Assess the primary healthcare needs (taking into account the cultural and } \\
\text { social setting of the patient) }\end{array}$ & 11 & 2.30 & 27 & 5.8 & 431 & 91.9 & 1 \\
\hline $\begin{array}{l}\text { B2. HP | Advise on health promotion, disease prevention and control, and healthy } \\
\text { lifestyle }\end{array}$ & 2 & 0.4 & 26 & 5.5 & 441 & 94 & 1 \\
\hline \multicolumn{8}{|l|}{ Medicines information and advice } \\
\hline $\begin{array}{l}\text { B3. MIA | Counsel patients on the appropriate use of medicines and devices (including } \\
\text { the selection, use, contraindications, storage, and side effects of non-prescription } \\
\text { and prescription medicines) taking into account patients preferences }\end{array}$ & 3 & 0.60 & 23 & 4.90 & 443 & 94.4 & 1 \\
\hline $\begin{array}{l}\text { B4. MIA / Identify sources, retrieve, evaluate, organise, assess and disseminate relevant } \\
\text { medicines information according to the needs of patients and clients and provide } \\
\text { appropriate information }\end{array}$ & 3 & 0.60 & 30 & 6.40 & 436 & 92.9 & 1 \\
\hline
\end{tabular}


Table 6 Overall rating of behaviours in the pharmaceutical care cluster

\begin{tabular}{|c|c|c|c|c|c|c|c|}
\hline \multirow[t]{2}{*}{ Pharmaceutical care competencies $(n=386)$} & \multicolumn{2}{|c|}{ Not relevant } & \multicolumn{2}{|c|}{ Low relevance } & \multicolumn{2}{|c|}{ Relevant } & \multirow[t]{2}{*}{ Group } \\
\hline & Count & Row $(N \%)$ & Count & Row (N\%) & Count & Row (N\%) & \\
\hline \multicolumn{8}{|l|}{ Assessment of medicines } \\
\hline $\begin{array}{l}\text { B5. AM | Appropriately select medicines (e.g. according to the patient, hospital, } \\
\text { government policy, etc.) }\end{array}$ & 18 & 4.7 & 40 & 10.4 & 328 & 85 & 1 \\
\hline $\begin{array}{l}\text { B6. AM | Identify, prioritise and act upon medicine-medicine interactions; } \\
\text { medicine-disease interactions; medicine-patient interactions; medicines-food } \\
\text { interactions }\end{array}$ & 43 & 11.1 & 83 & 21.5 & 260 & 67.4 & 2 \\
\hline \multicolumn{8}{|l|}{ Compounding medicines } \\
\hline $\begin{array}{l}\text { B7. CM | Prepare pharmaceutical medicines (e.g. extemporaneous, cytotoxic medicines), } \\
\text { determine the requirements for preparation (calculations, appropriate formulation, } \\
\text { procedures, raw materials, equipment etc.) }\end{array}$ & 25 & 6.5 & 61 & 15.8 & 300 & 77.7 & 1 \\
\hline $\begin{array}{l}\text { B8. CM | Compound under the good manufacturing practice for pharmaceutical (GMP) } \\
\text { medicines }\end{array}$ & 35 & 9.1 & 61 & 15.8 & 290 & 75.1 & 1 \\
\hline \multicolumn{8}{|l|}{ Dispensing } \\
\hline $\begin{array}{l}\text { B9. D | Accurately dispense medicines for prescribed and/or minor ailments and monitor } \\
\text { the dispense (re-checking the medicines) }\end{array}$ & 19 & 4.9 & 43 & 11.2 & 324 & 83.9 & 1 \\
\hline $\begin{array}{l}\text { B10. D | Accurately report defective or substandard medicines to the appropriate } \\
\text { authorities }\end{array}$ & 26 & 6.7 & 53 & 13.7 & 307 & 79.5 & 1 \\
\hline $\begin{array}{l}\text { B11. D | Appropriately validate prescriptions, ensuring that prescriptions are correctly } \\
\text { interpreted and legal }\end{array}$ & 16 & 4.1 & 41 & 10.6 & 329 & 85.2 & 1 \\
\hline B12. D | Dispense devices (e.g. Inhaler or a blood glucose meter) & 11 & 2.8 & 27 & 7 & 348 & 90.2 & 1 \\
\hline B13. D | Document and act upon dispensing errors & 50 & 13 & 44 & 11.4 & 292 & 75.6 & 2 \\
\hline $\begin{array}{l}\text { B14. D | Implement and maintain a dispensing error report system and a 'near misses' } \\
\text { report system }\end{array}$ & 43 & 11.1 & 46 & 11.9 & 297 & 76.9 & 2 \\
\hline B15. D | Label the medicines (with the required and appropriate information) & 14 & 5.2 & 20 & 3.6 & 352 & 91.2 & 1 \\
\hline B16. D | Learn from and act upon previous 'near misses' and 'dispensing errors & 19 & 4.9 & 27 & 7 & 340 & 88.1 & 1 \\
\hline \multicolumn{8}{|l|}{ Medicines } \\
\hline $\begin{array}{l}\text { B17. M | Advise patients on proper storage conditions of the medicines and ensure that } \\
\text { medicines are stored appropriately (e.g. humidity, temperature, expiry date, etc.) }\end{array}$ & 17 & 4.9 & 19 & 4.4 & 350 & 90.7 & 1 \\
\hline $\begin{array}{l}\text { B18. M | Appropriately select medicines formulation and concentration for minor } \\
\text { ailments (e.g. diarrhoea, constipation, cough, hay fever, insect bites, etc.) }\end{array}$ & 33 & 8.5 & 42 & 10.9 & 311 & 80.6 & 1 \\
\hline $\begin{array}{l}\text { B19. M | Ensure appropriate medicines, route, time, dose, documentation, action, form } \\
\text { and response for individual patients }\end{array}$ & 27 & 7 & 28 & 7.3 & 331 & 85.8 & 1 \\
\hline $\begin{array}{l}\text { B20. M | Package medicines to optimise safety (ensuring appropriate re-packaging and } \\
\text { labelling of the medicines) }\end{array}$ & 39 & 10.1 & 47 & 12.2 & 300 & 77.7 & 2 \\
\hline \multicolumn{8}{|l|}{ Monitor medicines therapy } \\
\hline $\begin{array}{l}\text { B21. MMT | Apply guidelines, medicines formulary system, protocols and treatment } \\
\text { pathways }\end{array}$ & 11 & 4.9 & 19 & 2.9 & 356 & 92.2 & 1 \\
\hline $\begin{array}{l}\text { B22. MMT | Ensure therapeutic medicines monitoring, impact and outcomes (including } \\
\text { objective and subjective measures) }\end{array}$ & 22 & 5.7 & 26 & 6.7 & 338 & 87.6 & 1 \\
\hline $\begin{array}{l}\text { B23. MMT | Identify, prioritise and resolve medicines management problems (including } \\
\text { errors) }\end{array}$ & 12 & 3.1 & 19 & 4.9 & 355 & 92 & 1 \\
\hline \multicolumn{8}{|l|}{ Patient consultation and diagnosis } \\
\hline B24. PCD | Apply first aid and act upon arranging follow-up care & 18 & 4.7 & 29 & 7.5 & 339 & 87.8 & 1 \\
\hline B25. PCD | Appropriately refer & 14 & 3.6 & 18 & 4.7 & 354 & 91.7 & 1 \\
\hline B26. PCD | | Assess and diagnose based on objective and subjective measures & 12 & 3.1 & 21 & 5.4 & 353 & 91.5 & 1 \\
\hline $\begin{array}{l}\text { B27. PCD | Discuss and agree with the patients the appropriate use of medicines, taking } \\
\text { into account patients preferences }\end{array}$ & 14 & 3.6 & 30 & 7.8 & 342 & 88.6 & 1 \\
\hline $\begin{array}{l}\text { B28. PCD | Document any intervention (e.g. document allergies, medicines and food, in } \\
\text { patient medicines history) }\end{array}$ & 21 & 5.4 & 43 & 11.1 & 322 & 83.4 & 1 \\
\hline $\begin{array}{l}\text { B29. PCD | Obtain, reconcile, review, maintain and update relevant patient medication } \\
\text { and diseases history }\end{array}$ & 18 & 4.7 & 28 & 7.3 & 340 & 88.1 & 1 \\
\hline
\end{tabular}


Table 7 Overall rating of behaviours in the organisation and management cluster

\begin{tabular}{|c|c|c|c|c|c|c|c|}
\hline \multirow[t]{2}{*}{ Organisation and management competencies $(n=328)$} & \multicolumn{2}{|c|}{ Not relevant } & \multicolumn{2}{|c|}{ Low relevance } & \multicolumn{2}{|c|}{ Relevant } & \multirow[t]{2}{*}{ Group } \\
\hline & Count & $\begin{array}{l}\text { Row } \\
\text { (N\%) }\end{array}$ & Count & $\begin{array}{l}\text { Row } \\
\text { (N\%) }\end{array}$ & Count & $\begin{array}{l}\text { Row } \\
\text { (N\%) }\end{array}$ & \\
\hline \multicolumn{8}{|l|}{ Budget and reimbursement } \\
\hline B30. BR | Acknowledge the organisational structure & 16 & 4.9 & 45 & 13.7 & 267 & 81.4 & 1 \\
\hline B31. BR | Effectively set and apply budgets & 20 & 6.1 & 53 & 16.2 & 255 & 77.7 & 1 \\
\hline B32. BR | Ensure appropriate claim for the reimbursement & 40 & 12.2 & 54 & 16.5 & 234 & 71.4 & 2 \\
\hline B33. BR | Ensure financial transparency & 21 & 6.4 & 45 & 13.7 & 262 & 79.9 & 1 \\
\hline B34. BR | Ensure proper reference sources for service reimbursement & 34 & 10.4 & 56 & 17.1 & 238 & 72.5 & 2 \\
\hline \multicolumn{8}{|l|}{ Human resources management } \\
\hline $\begin{array}{l}\text { B35. HRM | Demonstrate organisational and management skills (e.g. Know, understand } \\
\text { and lead on medicines management; risk management; self-management; } \\
\text { time management; people management; project management; } \\
\text { policy management.) }\end{array}$ & 8 & 2.4 & 23 & 7 & 297 & 90.6 & 1 \\
\hline B36. HRM | Identity and manage human resources and staffing issues & 13 & 4 & 37 & 11.3 & 278 & 84.8 & 1 \\
\hline $\begin{array}{l}\text { B37. HRM | Participate, collaborate, advice in therapeutic decision-making and use } \\
\text { appropriate referral in a multi-disciplinary team }\end{array}$ & 15 & 4.6 & 29 & 8.8 & 284 & 86.6 & 1 \\
\hline $\begin{array}{l}\text { B38. HRM | Recognise and manage the potential of each member of the staff and } \\
\text { utilise systems for performance management (e.g. carry out staff appraisals) }\end{array}$ & 12 & 3.7 & 33 & 10.1 & 283 & 86.3 & 1 \\
\hline B39. HRM | Recognise the value of the pharmacy team and of a multidisciplinary team & 7 & 2.1 & 25 & 7.6 & 296 & 90.2 & 1 \\
\hline B40. HRM | Support and facilitate staff training and professional development & 9 & 2.7 & 23 & 7 & 296 & 90.2 & 1 \\
\hline \multicolumn{8}{|l|}{ Improvement of service } \\
\hline B41. IS | Identify and implement new services (according to local needs) & 7 & 2.1 & 35 & 10.7 & 286 & 87.2 & 1 \\
\hline B42. IS | Resolve, follow up and prevent medicines related problems & 11 & 3.4 & 32 & 9.8 & 285 & 86.9 & 1 \\
\hline \multicolumn{8}{|l|}{ Procurement } \\
\hline $\begin{array}{l}\text { B43. P | Access reliable information and ensure the most cost-effective medicines in } \\
\text { the right quantities with the appropriate quality }\end{array}$ & 12 & 3.7 & 20 & 6.1 & 296 & 90.2 & 1 \\
\hline B44. P | Develop and implement contingency plan for shortages & 16 & 4.9 & 29 & 8.8 & 283 & 86.3 & 1 \\
\hline $\begin{array}{l}\text { B45. P | Efficiently link procurement to formulary, to push/pull system (supply chain } \\
\text { management) and payment mechanisms }\end{array}$ & 18 & 5.5 & 44 & 13.4 & 266 & 81.1 & 1 \\
\hline B46. P | Ensure there is no conflict of interest & 19 & 5.8 & 43 & 13.1 & 266 & 81.1 & 1 \\
\hline $\begin{array}{l}\text { B47. P | Select reliable suppliers of high-quality products (including appropriate } \\
\text { selection process, cost effectiveness, timely delivery) }\end{array}$ & 16 & 4.9 & 32 & 9.8 & 280 & 85.4 & 1 \\
\hline B48. P | Supervise procurement activities & 23 & 7.0 & 34 & 10.4 & 271 & 82.6 & 1 \\
\hline B49. P | Understand the tendering methods and evaluation of tender bids & 25 & 7.6 & 50 & 15.2 & 253 & 77.1 & 1 \\
\hline \multicolumn{8}{|l|}{ Supply chain and management } \\
\hline $\begin{array}{l}\text { B50. SCM | Demonstrate knowledge in store medicines to minimise errors and } \\
\text { maximise accuracy }\end{array}$ & 15 & 4.6 & 20 & 6.1 & 293 & 89.3 & 1 \\
\hline B51. SCM | Ensure accurately verification of rolling stocks & 16 & 4.9 & 30 & 9.1 & 282 & 86 & 1 \\
\hline $\begin{array}{l}\text { B52. SCM | Ensure effective stock management and running of service with the } \\
\text { dispensary }\end{array}$ & 17 & 5.5 & 18 & 5.2 & 293 & 89.3 & 1 \\
\hline B53. SCM | Ensure logistics of delivery and storage & 16 & 4.9 & 23 & 7 & 289 & 88.1 & 1 \\
\hline B54. SCM | Implement a system for documentation and record keeping & 14 & 4.3 & 21 & 6.4 & 293 & 89.3 & 1 \\
\hline B55. SCM | Take responsibility for quantification of forecasting & 22 & 7.0 & 23 & 6.7 & 283 & 86.3 & 1 \\
\hline \multicolumn{8}{|l|}{ Work place management } \\
\hline B56. WPM | Address and manage day to day management issues & 8 & 2.4 & 20 & 6.1 & 300 & 91.5 & 1 \\
\hline $\begin{array}{l}\text { B57. WPM | Demonstrate the ability to take accurate and timely decisions and } \\
\text { make appropriate judgments }\end{array}$ & 8 & 2.4 & 15 & 4.6 & 305 & 93 & 1 \\
\hline B58. WPM | Ensure the production schedules are appropriately plan and manage & 35 & 10.7 & 52 & 15.9 & 241 & 73.5 & 2 \\
\hline
\end{tabular}


Table 7 Overall rating of behaviours in the organisation and management cluster (Continued)

\begin{tabular}{|c|c|c|c|c|c|c|c|}
\hline \multirow[t]{2}{*}{ Organisation and management competencies $(n=328)$} & \multicolumn{2}{|c|}{ Not relevant } & \multicolumn{2}{|c|}{ Low relevance } & \multicolumn{2}{|c|}{ Relevant } & \multirow[t]{2}{*}{ Group } \\
\hline & $\overline{\text { Count }}$ & $\begin{array}{l}\text { Row } \\
\text { (N\%) }\end{array}$ & Count & $\begin{array}{l}\text { Row } \\
\text { (N\%) }\end{array}$ & Count & $\begin{array}{l}\text { Row } \\
\text { (N\%) }\end{array}$ & \\
\hline B59. WPM | Ensure the work time is appropriately plan and manage & 10 & 3 & 23 & 7 & 295 & 89.9 & 1 \\
\hline B60. WPM | Improve and manage the provision of pharmaceutical services & 8 & 2.4 & 20 & 6.1 & 300 & 91.5 & 1 \\
\hline B61. WPM | Recognise and manage pharmacy resources (e.g. financial, infrastructure) & 14 & 4.3 & 29 & 8.8 & 285 & 86.9 & 1 \\
\hline
\end{tabular}

Group: 1 = agreement, 2 = disagreement

The disagreement was also associated with 'patient-facing role' in practice area $[(P<0.05)$; Table 10$]$. A higher percentage of the respondents in the 'non-patient' facing areas of practice (this means area of pharmacy practice with little or no daily patient interactions such as industrial and academic pharmacy) ranked the behaviours that showed disagreement in the 'pharmaceutical care' (B6, B13, B14, B20) and 'organisation and management' cluster (B32, B34, B58) as 'not relevant' compared to respondents in the 'patient-facing' practice areas (such as hospital and community pharmacy) (Table 10). The converse was true for the research-related (B87 and B95) and quality control (B90) behaviours (Table 10).

\section{Perception of relevance per competency per country}

Inter-country variability in responses was assessed for each of the 20 competencies in the questionnaire. For ease of interpretation, the analysis included 426 replies from four countries: Kenya, Nigeria, South Africa and Ghana with the 10 countries that had fewer than 20 survey replies each excluded. The result showed similarity in weighting of relevance for the competencies in the 'pharmaceutical public health' (Pillia's trace $V=0.025, F=1.809, \mathrm{df}=6, p=0.094$ ), and 'professional and personal' (Pillia's trace $V=0.084, F=$ $1.270, \mathrm{df}=18, p=0.2$ ) clusters, respectively. Specific intercountry variability was observed in the 'pharmaceutical care' (Pillia's trace $V=0.083, F=1.624, \mathrm{df}=18, p=0.045$ ), and 'organisation and management' (Pillia's trace $V=0.136$, $F=2.279, \mathrm{df}=18, p=0.002)$ clusters.

Confirmatory post hoc analysis using Bonferroni correction showed the inter-country variability in responses observed within the 'pharmaceutical care' cluster was in three behaviours: B6 ['assessment of medicine (AM)]' and B25 and B27 ['patient consultation and diagnosis (PCD)'] competencies. This was between South Africa and Ghana [in B6: $N$ 'relevant' $=47 \%$ vs $71 \%$ )], Nigeria and Kenya [in B25: $N$ 'relevant' $=98$ vs $89 \%$ ], and Nigeria and Ghana [in B27: $N$ 'relevant' $=98$ vs $85 \%$ )]. In spite of the observed disparity in weighting of relevance, only South Africa showed a lack of consensus on relevance ( $N$ 'not relevant' $=15 \%$ ) for this cluster and this was in the $\mathrm{B} 6$ behaviour.

The disparity in the organisation and management cluster was in B32 ['budget and reimbursement (BR)'], B45 ['procurement (P)'] and B55 ['supply chain and management (SCM)'] competencies. More of the respondents from
Ghana rated the B32, B45 and B55 behaviours 'relevant' compared to Nigeria $(75 \%, 92 \%, 94 \%$ vs $70 \%, 70 \%, 79 \%$, respectively). A lack of consensus on relevance was observed in the South Africa and Nigeria group for the B32 $(N$ 'not relevant' $=11 \%)$ and B49 $(N$ 'not relevant' $=11 \%)$ behaviours, respectively. Since only Nigeria and South Africa showed a lack of consensus ( $N$ 'not relevant' $>10 \%$ ) on relevance to practice for three behaviours in the framework, it suggests that the inter-country variability in weighting of relevance observed in this study indicated differences in perception of 'degree of relevance' between countries. This variability is likely due to the disparity in sample composition in the respective countries given that Kenya had a higher percentage of the respondents in hospital practice (86\%) while Nigeria and South Africa on the other hand had less than $50 \%$ respectively. Also, more than a third of the respondents from South Africa were in academic pharmacy compared to Nigeria, Kenya and Ghana with less than $7 \%$ each.

\section{Discussion}

The disagreement observed in 10 behaviours in the GbCF v1 framework was mainly related to respondents' area of pharmacy practice and the corresponding patient-facing involvement, a finding that is consistent with evidence from previous research [26]. The disagreement in the four behaviours under the 'pharmaceutical care' cluster observed in academic and industrial pharmacy is also in line with the scope of practice of pharmacists in these areas given that they are not routinely involved in activities related to medicine assessment and medicines use. This also explains the disagreement observed in the three behaviours under the 'organisation and management' cluster.

On the other hand, the disagreement in the researchrelated behaviours (B87 and B95) under the 'professional and personal' cluster was not fully explained by area of pharmacy practice or 'patient-facing' involvement. A high percentage $(N>10 \%)$ of the respondents in academic and community pharmacy rated these same behaviours 'not relevant', thereby adding to the increasing body of evidence from other studies that suggest that pharmacists are not routinely involved in research [30-33] and perceive their researchrelated roles to be of low importance [34-37]. It also corroborates the findings of published studies from Australia [38], United Kingdom [39] and Thailand [40] that show that 
Table 8 Overall rating of behaviours in the professional and personal cluster

\begin{tabular}{|c|c|c|c|c|c|c|c|}
\hline \multirow[t]{2}{*}{ Professional and personal competencies $(n=305)$} & \multicolumn{2}{|c|}{ Not relevant } & \multicolumn{2}{|c|}{ Low relevance } & \multicolumn{2}{|c|}{ Relevant } & \multirow[t]{2}{*}{ Group } \\
\hline & $\overline{\text { Count }}$ & $\begin{array}{l}\text { Row } \\
\text { (N\%) }\end{array}$ & $\overline{\text { Count }}$ & $\begin{array}{l}\text { Row } \\
\text { (N\%) }\end{array}$ & $\overline{\text { Count }}$ & $\begin{array}{l}\text { Row } \\
\text { (N\%) }\end{array}$ & \\
\hline \multicolumn{8}{|l|}{ Communication skills } \\
\hline $\begin{array}{l}\text { B62. CS | Communicate clearly, precisely and appropriately while being a mentor } \\
\text { or tutor }\end{array}$ & 4 & 1.3 & 6 & 2 & 295 & 96.7 & 1 \\
\hline $\begin{array}{l}\text { B63. CS | Communicate effectively with health and social care staff, support staff, } \\
\text { patients, carer, family relatives and clients/customers, using lay terms and } \\
\text { checking understanding }\end{array}$ & 4 & 1.3 & 9 & 3 & 292 & 95.7 & 1 \\
\hline B64. CS | Demonstrate cultural awareness and sensitivity & 6 & 2.0 & 17 & 5.6 & 282 & 92.5 & 1 \\
\hline B65. CS | Tailor communications to patient needs & 5 & 1.6 & 15 & 4.9 & 285 & 93.4 & 1 \\
\hline $\begin{array}{l}\text { B66. CS | Use appropriate communication skills to build, report and engage with } \\
\text { patients, health and social care staff and voluntary services (e.g. verbal and } \\
\text { non-verbal) }\end{array}$ & 3 & $<0.1$ & 10 & 3.3 & 292 & 95.7 & 1 \\
\hline \multicolumn{8}{|l|}{ Continuing professional development (CPD) } \\
\hline B67. CPD | Document CPD activities & 10 & 3.3 & 36 & 11.8 & 259 & 84.9 & 1 \\
\hline B68. CPD | Engage with students/interns/residents & 12 & 3.9 & 28 & 9.2 & 265 & 86.9 & 1 \\
\hline B69. CPD | Evaluate currency of knowledge and skills & 8 & 2.6 & 25 & 8.2 & 272 & 89.2 & 1 \\
\hline B70. CPD | Evaluate learning & 8 & 2.6 & 25 & 8.2 & 272 & 89.2 & 1 \\
\hline B71. CPD | Identify if expertise needed outside the scope of knowledge & 9 & 3.0 & 31 & 10.2 & 265 & 86.9 & 1 \\
\hline B72. CPD | Identify learning needs & 7 & 2.3 & 28 & 9.2 & 270 & 88.5 & 1 \\
\hline B73. CPD | Recognise own limitations and act upon them & 5 & 1.6 & 20 & 6.6 & 280 & 91.8 & 1 \\
\hline B74. CPD | Reflect on performance & 4 & 1.3 & 14 & 4.6 & 287 & 94.1 & 1 \\
\hline \multicolumn{8}{|l|}{ Legal and regulatory practice } \\
\hline $\begin{array}{l}\text { B75. LRP | Apply and understands regulatory affairs and the key aspects of } \\
\text { pharmaceutical registration and legislation }\end{array}$ & 7 & 2.3 & 23 & 7.5 & 275 & 90.2 & 1 \\
\hline $\begin{array}{l}\text { B76. LRP | Apply knowledge in relation to the principals of business economics } \\
\text { and intellectual property rights including the basics of patent interpretation }\end{array}$ & 16 & 5.2 & 54 & 17.7 & 235 & 77.1 & 1 \\
\hline B77. LRP | Be aware of and identify the new medicines coming to the market & 4 & 1.3 & 25 & 8.2 & 276 & 90.5 & 1 \\
\hline B78. LRP | Comply with legislation for drugs with the potential for abuse & 5 & 1.6 & 11 & 3.6 & 289 & 94.8 & 1 \\
\hline B79. LRP | Demonstrate knowledge in Marketing and Sale & 24 & 7.9 & 75 & 24.6 & 206 & 67.5 & 1 \\
\hline B80. LRP | Engage with health and medicines policies & 3 & $<0.1$ & 31 & 10.2 & 271 & 88.9 & 1 \\
\hline $\begin{array}{l}\text { B81. LRP | Understand the steps needed to bring a medicinal product to the } \\
\text { market including the safety, quality, efficacy and pharmacoeconomic } \\
\text { assessments of the product }\end{array}$ & 18 & 5.9 & 41 & 13.4 & 246 & 80.7 & 1 \\
\hline \multicolumn{8}{|l|}{ Professional and ethical practice } \\
\hline B82. PEP | Demonstrate awareness of local/national codes of ethics & 5 & 1.6 & 14 & 4.6 & 286 & 93.8 & 1 \\
\hline $\begin{array}{l}\text { B83. PEP | Ensure confidentiality (with the patient and other healthcare } \\
\text { professionals) }\end{array}$ & 4 & 1.3 & 10 & 3.3 & 291 & 95.4 & 1 \\
\hline B84. PEP | Obtain patient consent (it can be implicit in occasions) & 10 & 3.3 & 21 & 6.9 & 274 & 89.8 & 1 \\
\hline B85. PEP | Recognise own limitations & 5 & 1.6 & 14 & 4.6 & 286 & 93.8 & 1 \\
\hline B86. PEP | Take responsibility for own action and for patient care & 5 & 1.6 & 11 & 3.6 & 289 & 94.8 & 1 \\
\hline \multicolumn{8}{|l|}{ Quality assurance and research in the work place } \\
\hline $\begin{array}{l}\text { B87. QARWP | Apply research findings and understand the benefit risk } \\
\text { (e.g. pre-clinical, clinical trials, experimental clinical-pharmacological } \\
\text { research and risk management) }\end{array}$ & 34 & 11.1 & 48 & 15.7 & 223 & 73.1 & 2 \\
\hline $\begin{array}{l}\text { B88. QARWP | Audit quality of service (ensure that they meet local and national } \\
\text { standards and specifications) }\end{array}$ & 26 & 8.5 & 34 & 11.1 & 245 & 80.3 & 1 \\
\hline B89. QARWP | Developed and implement Standing Operating Procedures (SOP's) & 17 & 5.6 & 17 & 5.6 & 271 & 88.9 & 1 \\
\hline $\begin{array}{l}\text { B90. QARWP | Ensure appropriate quality control tests are performed and } \\
\text { managed appropriately }\end{array}$ & 39 & 12.8 & 54 & 17.7 & 212 & 69.5 & 2 \\
\hline B91. QARWP | Ensure medicines are not counterfeit and quality standards & 16 & 5.2 & 24 & 7.9 & 265 & 86.9 & 1 \\
\hline
\end{tabular}


Table 8 Overall rating of behaviours in the professional and personal cluster (Continued)

\begin{tabular}{|c|c|c|c|c|c|c|c|}
\hline \multirow[t]{2}{*}{ Professional and personal competencies $(n=305)$} & \multicolumn{2}{|c|}{ Not relevant } & \multicolumn{2}{|c|}{ Low relevance } & \multicolumn{2}{|c|}{ Relevant } & \multirow[t]{2}{*}{ Group } \\
\hline & Count & $\begin{array}{l}\text { Row } \\
\text { (N\%) }\end{array}$ & $\overline{\text { Count }}$ & $\begin{array}{l}\text { Row } \\
\text { (N\%) }\end{array}$ & $\overline{\text { Count }}$ & $\begin{array}{l}\text { Row } \\
\text { (N\%) }\end{array}$ & \\
\hline $\begin{array}{l}\text { B92. QARWP / Identify and evaluate evidence-base to improve the use of medicines } \\
\text { and services }\end{array}$ & 16 & 5.2 & 32 & 10.5 & 257 & 84.3 & 1 \\
\hline $\begin{array}{l}\text { B93. QARWP | Identify, investigate, conduct, supervise and support research at the } \\
\text { workplace (enquiry-driven practice) }\end{array}$ & 29 & 9.5 & 48 & 15.7 & 228 & 74.8 & 1 \\
\hline $\begin{array}{l}\text { B94. QARWP | Implement, conduct and maintain a report system of pharmacovigilance } \\
\text { (e.g. report adverse drug reactions) }\end{array}$ & 17 & 5.9 & 18 & 5.6 & 270 & 88.5 & 1 \\
\hline B95. QARWP | Initiate and implement audit and research activities & 33 & 10.8 & 52 & 17.5 & 220 & 72.1 & 2 \\
\hline \multicolumn{8}{|l|}{ Self-management } \\
\hline B96. SM | Apply assertiveness skills (inspire confidence) & 5 & 1.6 & 9 & 3 & 291 & 95.4 & 1 \\
\hline B97. SM | Demonstrate leadership and practice management skills, initiative and efficiency & 4 & 1.3 & 12 & 3.9 & 289 & 94.8 & 1 \\
\hline B98. SM | Document risk management (e.g. critical incidents) & 14 & 4.6 & 28 & 9.2 & 263 & 86.2 & 1 \\
\hline B99. SM | Ensure punctuality & 1 & $<0.1$ & 10 & 3.3 & 294 & 96.4 & 1 \\
\hline B100. SM | Prioritise work and implement innovative ideas & 4 & 1.3 & 12 & 3.9 & 289 & 94.8 & 1 \\
\hline
\end{tabular}

Group: 1 = agreement, 2 = disagreement

pharmacists generally perceive research-related behaviours and competencies included in developmental frameworks to be relatively low in relevance and rank them accordingly. Time constraints due to workload and a lack of supporting environment for pharmacy research are some of the barriers to participation in research-related activities in the workplace reported in existing literature [38, 41, 42]. Given that the survey respondents in our study included international pharmacists from different areas of pharmacy practice and with varying length of practice experience, this finding

Table 9 Distribution of the 'not relevant' ratings in relation to area of pharmacy practice for the 10 behaviours showing disagreement

\begin{tabular}{|c|c|c|c|c|c|c|c|c|c|c|}
\hline \multirow[t]{2}{*}{ Cluster } & \multirow[t]{2}{*}{ Competencies } & \multirow[t]{2}{*}{ Behaviours } & \multicolumn{6}{|c|}{ Area of practice (\%N 'not relevant') } & \multirow[t]{2}{*}{$x^{2}$ value } & \multirow[t]{2}{*}{$p$} \\
\hline & & & Acad. & Admin. & Comm. & Hosp. & Indus. & Others $^{\mathrm{a}}$ & & \\
\hline \multirow[t]{4}{*}{$\begin{array}{l}\text { Pharmaceutical } \\
\text { care }\end{array}$} & $\begin{array}{l}\text { Assessment } \\
\text { of medicines }\end{array}$ & $\begin{array}{l}\text { [B6] Identify, prioritise and act upon } \\
\text { medicine-medicine interactions; } \\
\text { medicine-disease interactions; } \\
\text { medicine-patient interactions; } \\
\text { medicines-food interactions ( } n=43 \text { ) }\end{array}$ & 20 & 9.5 & 0 & 11.6 & 21.9 & 7.1 & 23.5 & 0.01 \\
\hline & Dispensing & $\begin{array}{l}\text { [B13] Document and act upon } \\
\text { dispensing errors }(n=50)\end{array}$ & 14.3 & 19 & 20 & 7.6 & 21.9 & 35.7 & 36.9 & $<0.001$ \\
\hline & & $\begin{array}{l}\text { [B14] Implement and maintain a } \\
\text { dispensing error report system and } \\
\text { a 'near misses' report system }(n=43)\end{array}$ & 17.1 & 14.3 & 20.3 & 7.1 & 12.5 & 14.3 & 15.9 & 0.1 \\
\hline & Medicines & $\begin{array}{l}\text { [B20] Package medicines to optimise } \\
\text { safety [ensuring appropriate re-packaging } \\
\text { and labelling of the medicines] }(n=39)\end{array}$ & 20 & 9.5 & 16.9 & 4.4 & 25 & 14.3 & 31.9 & $<0.001$ \\
\hline \multirow{3}{*}{$\begin{array}{l}\text { Organisation } \\
\text { and } \\
\text { management }\end{array}$} & $\begin{array}{l}\text { Budget and } \\
\text { reimbursement }\end{array}$ & $\begin{array}{l}\text { [B32] Ensure appropriate claim for } \\
\text { reimbursement }(n=40)\end{array}$ & 24 & 5 & 10.9 & 8.8 & 24 & 27.3 & 20.1 & 0.03 \\
\hline & & $\begin{array}{l}\text { [B34] Ensure proper reference sources for } \\
\text { service reimbursement }(n=34)\end{array}$ & 18.2 & 5 & 10.9 & 7.8 & 16 & 27.3 & 16.8 & 0.08 \\
\hline & $\begin{array}{l}\text { Workplace } \\
\text { management }\end{array}$ & $\begin{array}{l}\text { [B58] Ensure production schedules are } \\
\text { appropriately planned and managed }(n=35)\end{array}$ & 15.2 & 5 & 19.6 & 6.7 & 20 & 18.2 & 17.4 & 0.08 \\
\hline \multirow[t]{3}{*}{$\begin{array}{l}\text { Professional } \\
\text { and personal }\end{array}$} & $\begin{array}{l}\text { Quality } \\
\text { assurance and } \\
\text { research in the } \\
\text { workplace }\end{array}$ & $\begin{array}{l}\text { [B87] Apply research findings and understand } \\
\text { the benefit risk [e.g. pre-clinical, clinical trials, } \\
\text { experimental clinical-pharmacological research } \\
\text { and risk management] }(n=34)\end{array}$ & 12.5 & 5 & 20.9 & 10.2 & 9.1 & 0 & 20.4 & 0.03 \\
\hline & & $\begin{array}{l}\text { [B90] Ensure appropriate quality control tests are } \\
\text { performed and managed appropriately }(n=39)\end{array}$ & 12.5 & 0 & 25.6 & 11.9 & 9.1 & 9.1 & 22.8 & 0.01 \\
\hline & & $\begin{array}{l}\text { [B95] Initiate and implement audit and research } \\
\text { activities }(n=33)\end{array}$ & 12.5 & 5 & 20.9 & 9 & 9.1 & 0 & 15.78 & 0.11 \\
\hline
\end{tabular}

Acad. academic pharmacy, Admin. administrative pharmacy, Comm. community pharmacy, Hosp. hospital pharmacy, Indus. industrial pharmacy ancludes areas of pharmacy practice with fewer than 20 replies (these were pharmacy information [11], military and emergency pharmacy [2] and laboratory and medicines control pharmacy [4]) 
Table 10 Distribution of the 'not relevant' ratings in relation to patient-facing component in area of pharmacy practice for the 10 behaviours showing disagreement

\begin{tabular}{|c|c|c|c|c|c|c|c|c|c|c|}
\hline \multirow[t]{2}{*}{ Cluster } & \multirow[t]{2}{*}{ Competency } & \multirow[t]{2}{*}{ Behaviour } & \multicolumn{3}{|c|}{ Patient-facing sectors* (N\%) } & \multicolumn{3}{|c|}{ Non patient-facing sectors ${ }^{\natural}$ (N\%) } & \multirow[t]{2}{*}{$x^{2}$ value } & \multirow[t]{2}{*}{$p$} \\
\hline & & & $\begin{array}{l}\text { Not } \\
\text { relevant }\end{array}$ & $\begin{array}{l}\text { Low } \\
\text { relevance }\end{array}$ & Relevant & $\begin{array}{l}\text { Not } \\
\text { relevant }\end{array}$ & $\begin{array}{l}\text { Low } \\
\text { relevance }\end{array}$ & Relevant & & \\
\hline \multirow[t]{4}{*}{$\begin{array}{l}\text { Pharmaceutical } \\
\text { care }\end{array}$} & $\begin{array}{l}\text { Assessment } \\
\text { of medicines }\end{array}$ & $\begin{array}{l}\text { [B6] Identify, prioritise and } \\
\text { act upon medicine-medicine } \\
\text { interactions; medicine-disease } \\
\text { interactions; medicine-patient } \\
\text { interactions; medicine-food } \\
\text { interactions ( } n=43 \text { ) }\end{array}$ & 9.1 & 21.1 & 69.8 & 18.2 & 22.7 & 59.1 & 6.3 & 0.04 \\
\hline & \multirow[t]{2}{*}{ Dispensing } & $\begin{array}{l}\text { [B13] Document and act upon } \\
\text { dispensing errors }(n=50)\end{array}$ & 11.4 & 11.4 & 77.2 & 18.2 & 11.4 & 70.5 & 2.8 & 0.25 \\
\hline & & $\begin{array}{l}\text { [B14] Implement and maintain } \\
\text { a dispensing error report } \\
\text { system and a 'near misses' } \\
\text { report system }(n=43)\end{array}$ & 10.1 & 13.4 & 76.5 & 14.8 & 6.8 & 78.4 & 3.87 & 0.15 \\
\hline & Medicines & $\begin{array}{l}\text { [B20] Package medicines to } \\
\text { optimise safety [ensuring } \\
\text { appropriate re-packaging and } \\
\text { labelling of the medicines] } \\
(n=39)\end{array}$ & 7.4 & 11.7 & 80.9 & 19.3 & 13.6 & 67 & 11.45 & 0.003 \\
\hline \multirow{3}{*}{$\begin{array}{l}\text { Organisation } \\
\text { and } \\
\text { management }\end{array}$} & \multirow[t]{2}{*}{$\begin{array}{l}\text { Budget and } \\
\text { reimbursement }\end{array}$} & $\begin{array}{l}\text { [B32] Ensure appropriate claim } \\
\text { for the reimbursement }(n=40)\end{array}$ & 10 & 18.4 & 71.6 & 19.2 & 10.3 & 70.5 & 6.56 & 0.04 \\
\hline & & $\begin{array}{l}\text { [B34] Ensure proper reference } \\
\text { sources for service } \\
\text { reimbursement }(n=34)\end{array}$ & 9.2 & 16.8 & 74 & 14.1 & 17.9 & 67.9 & 1.72 & 0.44 \\
\hline & $\begin{array}{l}\text { Work place } \\
\text { management }\end{array}$ & $\begin{array}{l}\text { [58] Ensure the production } \\
\text { schedules are appropriately } \\
\text { plan and manage }(n=35)\end{array}$ & 9.6 & 18.4 & 72 & 14.1 & 7.7 & 78.2 & 5.74 & 0.06 \\
\hline \multirow[t]{3}{*}{$\begin{array}{l}\text { Professional } \\
\text { and personal }\end{array}$} & \multirow[t]{3}{*}{$\begin{array}{l}\text { Quality } \\
\text { assurance and } \\
\text { research in the } \\
\text { workplace }\end{array}$} & $\begin{array}{l}\text { [B87] Apply research findings } \\
\text { and understand the benefit } \\
\text { risk [e.g. pre-clinical, clinical } \\
\text { trials, experimental clinical- } \\
\text { pharmacological research } \\
\text { and risk management] }(n=34)\end{array}$ & 11.7 & 18.2 & 82.4 & 9.5 & 8.1 & 70.1 & 5.02 & 0.08 \\
\hline & & $\begin{array}{l}\text { [B90] Ensure appropriate } \\
\text { quality control tests are } \\
\text { performed and managed } \\
\text { appropriately }(n=39)\end{array}$ & 14.3 & 21.2 & 64.5 & 8.1 & 6.8 & 85.1 & 11.72 & 0.003 \\
\hline & & $\begin{array}{l}\text { [B95] Initiate and implement } \\
\text { audit and research activities } \\
(n=33)\end{array}$ & 11.3 & 19.9 & 68.8 & 9.5 & 8.1 & 82.4 & 6.19 & 0.05 \\
\hline
\end{tabular}

*Pharmacy areas involving daily patient interactions including hospital and community pharmacy

"Pharmacy areas not involving daily patient interactions including industrial, academic, administrative, laboratory and medicine control, and pharmacy information

highlights the need to scale up efforts to build research capacity in this region.

Of particular interest is the finding that a high percentage $(N>15 \%)$ of community pharmacists from the countries represented in this survey ranked two dispensing-related behaviours: B13 (document and act upon dispensing errors) and B14 (implement and maintain a dispensing error report system and a near miss report system) 'not relevant' to practice. This suggests community pharmacy respondents from these countries do not routinely carry out these activities although this may have been due to the response rate and/or that the pharmacists were self-selecting. However, available evidence suggests this may also be related to the peculiarities of community pharmacy practice in countries with severe health workforce shortages such as Nigeria [43] and Zambia [44]. Studies show that dispensing activities in community pharmacies in Nigeria are mainly carried out by pharmacy assistants and in some instances, by sales personnel or clerks [43].

Furthermore, the finding may also be related to evidence that suggest that many countries including those in Africa either lack a defined medication error reporting system $[45,46]$ or where available such systems are primarily independent and/or based within a specific healthcare facility $[45,47]$. Given the broad similarities in pharmacy practice reported in countries within the African region 
[48] and published reports of high incidence of patient harm due to medication errors in some of the countries represented in this survey $[49,50]$. This finding underscores the need to review current practice and incorporate robust dispensing and medication error reporting processes in community practice with oversight functions by pharmacists in order to assure patient safety.

Homogeneity in sample responses and the overall survey results indicate minimal disparity between countries in perception of relevance to practice for majority of the behaviours in the GbCF v1. This finding corroborates evidence from previous research [26] and provides evidence that was previously lacking on the relevance of the GbCF v1 competencies in these countries. The finding is in consonance with similar evidence from the field of medicine that demonstrates the relevance of the Canadian CanMEDS Physician Competency Framework to medical practice in the Netherlands [51], Denmark [52, 53] and Australia [54]. It is also in line with evidence from studies that show consensus between countries in Europe on the relevance of a core set of competencies for pharmacy education and practice $[42,55]$.

Although evidence from global studies have shown that continuous professional development (CPD) is mandatory in many countries in Africa, none of the countries represented in this survey have reported the availability of a validated competency framework for early career pharmacy practice $[7,56]$. Studies conducted in Ghana, Ethiopia and Sudan suggest that the lack of a structured post-registration pathway for skills development contribute to the comparatively lower levels of job satisfaction shown by early career pharmacists in these countries [57-59]. Our findings therefore provide preliminary evidence on the validity of a core set of competencies that can be further adapted to country context and used to design skill development and learning activities for pre- and in-service early career pharmacy practitioners in these countries. Our findings also suggests the feasibility of adapting the GbCF v1 to develop country-specific frameworks for use in facilitating performance improvement and identifying learning needs particularly in the four countries with comparatively high number of replies in this study.

This study has some limitations. The length of the survey questionnaire (105 questions presented over six pages) may have negatively impacted on the number of replies received. Findings from a meta-analysis of randomised controlled trials show that the odds of a response decreases by more than half as the number of pages of a survey questionnaire increases [OR $0.39,95 \%$ CI 0.34 to 0.45 ] [60]. This was particularly obvious with the consistent decrease in number of replies per additional competency cluster in the survey questionnaire (Additional file 1). Nonetheless, research also demonstrates that the variation in response rates per page of a questionnaire does not affect the quality of the overall responses received [61].

Online surveys are generally associated with low response rates particularly because it restricts the target populations to individuals with internet access $[62,63]$. This implies that potential respondents without Internet access were excluded from this survey, a feature that is significant given that our study was conducted in countries that have been shown to have comparatively higher cost and lower Internet accessibility $[64,65]$. However, the geographical location of the survey population, limited resources and time available for this research precluded the use of a telephone or postal survey. Participant self-selection and the non-probabilistic sample obtained via the purposive and snowball sampling technique in our study likely limits the generalisability of our findings. Studies show that self-selected participants are likely to be more intrinsically motivated than the general population [66]. This non-random sampling method was undertaken due to challenges with obtaining a sampling frame for the respective countries. For this same reason, it was difficult to estimate an optimal sample size a priori and to calculate a response rate. In spite of these limitations, the methods used in our study are established and pragmatic evidence-based approaches in pharmacy practice research $[26,38-40]$. Furthermore, given that our study was an exploratory survey, our findings provide useful information on pharmacists' perception of relevance to practice of the competencies and behaviours contained in the GbCF v1 framework in the countries represented.

Further work is necessary to qualitatively explore expert opinion and obtain insight from other stakeholders including policy-makers and pharmacy leaders on the validity of these competencies in the respective countries. Also, a larger scale validation study is needed to obtain further inputs from practitioners in non-patient-facing roles such as industrial, administrative and academic pharmacy in this region. This will provide an opportunity for further review of the GbCF v1 competencies in relation to these specific areas of practice.

\section{Conclusion}

The majority (90\%) of the competencies in the framework as relevant to practice for the respondents in this survey, although there are some emergent differences in weighting of relevance between the countries represented. Overall, the findings provide preliminary evidence that was previously lacking on the relevance of the GbCF v1 competencies to pharmacy practice in these countries. 


\section{Appendix}

Table 11 FIP member organisations and the respective countries in Africa

\begin{tabular}{|c|c|c|}
\hline $\mathrm{S} / \mathrm{N}$ & Organisation & Country \\
\hline 1. & Pharmacy Council of Ghana & Ghana \\
\hline 2. & Pharmaceutical Society of Kenya & Kenya \\
\hline 3. & Ordre National des Pharmaciens de Madagascar & Madagascar \\
\hline 4. & Pharmaceutical Association of Mauritius & Mauritius \\
\hline 5. & $\begin{array}{l}\text { Conseil Regional des Pharmaciens d'officine du } \\
\text { Nord }\end{array}$ & Morocco \\
\hline 6. & $\begin{array}{l}\text { Conseil National de l'ordre des Pharmaciens du } \\
\text { Mali }\end{array}$ & Mali \\
\hline 7. & Pharmaceutical Society of Nigeria & Nigeria \\
\hline 8. & Rwanda Pharmacists Association & Rwanda \\
\hline 9. & Ordre National des Pharmaciens du Senegal & Senegal \\
\hline 10. & Pharmaceutical Society of South Africa & South Africa \\
\hline 11. & Sudanese Pharmacists Union & Sudan \\
\hline 12. & Pharmaceutical society of Uganda & Uganda \\
\hline 13. & Pharmaceutical Society of Zambia & Zambia \\
\hline 14. & Pharmaceutical Society of Zimbabwe & Zimbabwe \\
\hline 15. & Ordre National des Pharmaciens du Burkina Faso & Burkina Faso \\
\hline 16. & $\begin{array}{l}\text { Conseil National de L'ordre des Pharmaciens du } \\
\text { Cameroun }\end{array}$ & Cameroun \\
\hline 17. & $\begin{array}{l}\text { Ordre National des Pharmaciens du Tchad } \\
\text { N'Djamena }\end{array}$ & Chad \\
\hline 18. & $\begin{array}{l}\text { Comseil National de l'ordre des Pharmaciens du } \\
\text { Congo }\end{array}$ & Congo \\
\hline 19. & Pharmaceutical Society of Egypt & Egypt \\
\hline 20. & $\begin{array}{l}\text { Syndicate of Pharmacists in Arab Republic of } \\
\text { Egypt }\end{array}$ & Egypt \\
\hline 21. & Eritean Pharmaceutical Association & Eritea \\
\hline 22. & Ethiopian Pharmaceutical Association & Ethiopia \\
\hline 23. & $\begin{array}{l}\text { Conseil National de l'ordre des Pharmaciens de } \\
\text { Guinea Conakry }\end{array}$ & $\begin{array}{l}\text { Republic of } \\
\text { Guinea }\end{array}$ \\
\hline 24. & $\begin{array}{l}\text { Conseil National de l'ordre des Pharmaciens de } \\
\text { Cote d'Ivoire }\end{array}$ & Cote d'Ivoire \\
\hline
\end{tabular}

\section{Additional file}

Additional file 1: Survey Questionnaire. (DOCX $63 \mathrm{~kb}$ )

\section{Abbreviations}

AM: Assessment of medicine competency; BR: Budget and reimbursement competency; D: Dispensing competency; FIP: The International Pharmaceutical Federation; FIPEd: The International Pharmaceutical Federation Education Initiative; GbCF v1: Global Competency Framework version 1; M: Medicines competency; OR: Odds ratio; P: Procurement competency; PCD: Patient consultation and diagnosis competency; SCM: Supply chain and management competency; SPSS v22: Statistical Package for the Social Sciences version 22

\section{Acknowledgements}

The authors thank Charles Ofei-Palm (Ghana), Onyimbo Kerama (Kenya), Prof. Sabiha Essack, Susan Buekes and GT Mahlatsi (South Africa), and Unoma
Onugbolu and Kamilu Labaran (Nigeria) for their assistance with disseminating survey invite to pharmacists in their respective countries. We also thank the pharmacy leadership bodies in the countries represented in the survey for their interest in participating in our study.

\section{Funding}

This research received no specific grant from any funding agency in the public, commercial or not-for-profit sectors.

\section{Availability of data and materials}

All authors had complete access to the data that supported the research.

\section{Authors' contributions}

$I B$ conceived the study with inputs from $A B$ and $A U$. $A U$ designed the study, $I B$ and $A B$ provided input on methodology and reviewed interpretation of the outcome of the data analysis. All three authors read the draft manuscript for intellectual content and approved the final version.

\section{Ethics approval and consent to participate}

This study was exempted from formal ethical approval by the research ethics committee as it did not involve the use of identifiable patient information or data, rather the study recruited pharmacists and sought their views by virtue of their professional roles.

Participants completed a consent page prior to participating in the survey.

\section{Consent for publication}

N/A

\section{Competing interests}

The authors declare that they have no competing interests.

\section{Publisher's Note}

Springer Nature remains neutral with regard to jurisdictional claims in published maps and institutional affiliations.

\section{Author details}

${ }^{1}$ University College London School of Pharmacy, London, United Kingdom.

${ }^{2}$ Faculty of Pharmacy and Pharmaceutical Sciences, Monash University

(Parkville Campus), Melbourne, Australia.

Received: 26 January 2017 Accepted: 16 March 2018

Published online: 02 April 2018

\section{References}

1. Bond CA, Raehl CL. Clinical pharmacy services, pharmacy staffing, and hospital mortality rates. Pharmacother J Hum Pharmacol Drug Ther. 2007; 27(4):481-93.

2. Fairbanks RJ, Hildebrand JM, Kolstee KE, Schneider SM, Shah MN. Medical and nursing staff highly value clinical pharmacists in the emergency department. Emerg Med J. 2007;24(10):716-8.

3. Giberson S, Yoder S, Lee MP. Improving patient and health system outcome through advanced pharmacy practice. [Internet]. Office of the Chief Pharmacist, U.S. Public Health Service; 2011 Dec [cited 2012 Oct 24] p. 1-95. (Report to the Surgeon General). Available from: http://www.usphs.gov/ corpslinks/pharmacy/sc_comms_sg_report.aspx.

4. Jacknin G, Nakamura T, Smally AJ, Ratzan RM. Using pharmacists to optimize patient outcomes and costs in the ED. Am J Emerg Med. 2014;32(6):673-7.

5. Lada P, Delgado G. Documentation of pharmacists' interventions in an emergency department and associated cost avoidance. Am J Health Syst Pharm. 2007;64(1):63-8.

6. Austin Z. CPD and revalidation: our future is happening now. Res Soc Adm Pharm. 2013;9(2):138-41.

7. International Pharmaceutical Federation. The 2012 FIP global pharmacy workforce report. The Hague: International Pharmaceutical Federation; 2012

8. International Pharmaceutical Federation (FIP). Advanced practice and specialisation in pharmacy: global report 2015 [Internet]. The Hague, Netherlands: International Pharmaceutical Federation; 2015. Available from: http://www.fip.org/files/fip/PharmacyEducation/Adv_and_Spec_Survey/ FIPEd_Advanced_2015_web_v2.pdf. Accessed Mar 2018.

9. Global Health Workforce Alliance. A universal truth: no health without a workforce. Brazil: Global Health Workforce Alliance and World Health 
Organization; 2013. p. 90. Available from: http://www.who.int/workforcealliance/ knowledge/resources/GHWA-a_universal_truth_report.pdf?ua=1.

10. International Pharmaceutical Federation (FIP). Global pharmacy workforce intelligence: trends report. The Hague: International Pharmaceutical Federation; 2015. Available from: http://www.fip.org/files/fip/ PharmacyEducation/Trends/FIPEd_Trends_report_2015_web.pdf.

11. About FIP_FIP_International Pharmaceutical Federation [Internet]. [cited 2017 Jan 25]. Available from: https://www.fip.org/?page=menu_about.

12. Bates I, Bruno A. Competence in the global pharmacy workforce: a discussion paper. Int Pharm J. 2008;23(2):30-3.

13. Bruno A, Bates I, Brock T, Anderson C. Towards a global competency framework. Am J Pharm Educ. 2010;74(3):1-2.

14. Antoniou S, Webb DG, McRobbie D, Davies JG, Wright J, Quinn J, et al. A controlled study of the general level framework: results from the South of England competency study. Pharm Educ. 2005;5:201-7.

15. Coombes I, Avent M, Cardiff L, Bettenay K, Coombes J, Whitfield K, et al. Improvement in pharmacist's performance facilitated by an adapted competency-based general level framework. J Pharm Pract Res. 2010; 40(2):111-8

16. Rutter V, Wong C, Coombes I, Cardiff L, Duggan C, Yee M-L, et al. Use of a general level framework to facilitate performance improvement in hospital pharmacists in Singapore. Am J Pharm Educ. 2012;76(6):107.

17. Svetlana S, Ivana T, Tatjana C, Duskana K, Bates I. Evaluation of competences at the community pharmacy settings. Indian J Pharm Educ Res. 2014;48(4):22-30.

18. Meštrović A, Staničić Ž, Hadžiabdić MO, Mucalo I, Bates I, Duggan C, et al. Individualized education and competency development of Croatian community pharmacists using the general level framework. Am J Pharm Educ. 2012;76(2):23.

19. Meštrović A, Staničić Z, Hadžiabdić MO, Mucalo I, Bates I, Duggan C, et al. Evaluation of Croatian community pharmacists' patient care competencies using the general level framework. Am J Pharm Educ. 2011;75(2). Article 36.

20. Mills E, Bates I, Farmer D, Davies G, Webb DG. The general level framework: use in primary care and community pharmacy to support professional development. Int J Pharm Pract. 2008;16(5):325-31.

21. FIP Education Initiatives. A global competency framework for services provided by pharmacy workforce: International Pharmaceutical Federation; 2012. p. 21. https://www.fip.org/files/fip/PharmacyEducation/GbCF/GbCF_v1_ online_A4.pdf.

22. International Pharmaceutical Federation (FIP). 2013 FIPEd global education report. The Haque: International Pharmaceutical Federation; 2013. 52 p.

23. International Pharmaceutical Federation. Transforming our workforce [Internet]. International Pharmaceutical Federation; 2016 [cited 2017 Jan 25]. Available from: https://www.fip.org/files/fip/PharmacyEducation/2016 report/FIPEd_Transform_2016_online_version.pdf.

24. The Pharmaceutical Society of Ireland. Core competency framework for pharmacists. Dublin: Pharmaceutical Society of Ireland; 2013. Available from: http://www.thepsi.ie/Libraries/Publications/PSI_Core_Competency_ Framework_for_Pharmacists.sflb.ashx.

25. Brown AN, Gilbert BJ, Bruno AF, BPharm GMC. The pharmacy competency framework for Pacific Island countries. J Pharm Pract Res. 2012;42(4):268-72.

26. Bruno AF. The feasibility, development and validation of a global competency framework for pharmacy education, PhD thesis. School of Pharmacy, University of London. London: School of Pharmacy, University of London; 2011.

27. Bewick V, Cheek L, Ball J. Statistics review 8: qualitative data-tests of association. Crit Care. 2004;8(1):46-53.

28. Cohen J. Statistical power analysis for the behavioural sciences. Hillsdale: Lawrence Erlbaum Associates; 1988.

29. Weisburd D, Britt C. Measures of association for nominal and ordinal variables. In: Statistics in criminal justice. Third. New York: Springer US; 2007. p. 335-380. Available from: https://doi.org/10.1007/978-0-387-34113-2_13.

30. Armour C, Brillant M, Krass I. Pharmacists' views on involvement in pharmacy practice research: strategies for facilitating participation. Pharm Pract. 2007:5(2):59-66.

31. Awaisu A, Bakdach D, Elajez RH, Zaidan M. Hospital pharmacists' selfevaluation of their competence and confidence in conducting pharmacy practice research. Saudi Pharm J. 2014;(0). Available from: http://www. sciencedirect.com/science/article/pii/S1319016414001121. Accessed Mar 2018.

32. Fagan SC, Touchette D, Smith JA, Sowinski KM, Dolovich L, Olson KL, et al. The state of science and research in clinical pharmacy. Pharmacother J Hum Pharmacol Drug Ther. 2006;26(7):1027-40.
33. Rosenbloom K, Taylor K, Harding G. Community pharmacists' attitudes towards research. Int J Pharm Pract. 2000;8(2):103-10.

34. Hébert J, Laliberté M-C, Berbiche D, Martin E, Lalonde L. The willingness of community pharmacists to participate in a practice-based research network. Can Pharm J CPJ. 2013;146(1):47-54.

35. Kanjanarach $T$, Numchaitosapol $S$, Jaisa-ard R. Thai pharmacists' attitudes and experiences of research. Res Soc Adm Pharm. 2012;8(6):e58-9.

36. Liddell $\mathrm{H}$. Attitudes of community pharmacists regarding involvement in research. Pharm J. 1996;256:905-7.

37. Saini B, Brillant M, Filipovska J, Gelgor L, Mitchell B, Rose G, et al. Factors influencing Australian community pharmacists' willingness to participate in research projects: an exploratory study. Int J Pharm Pract. 2006;14(3):179-88.

38. Carrington C, Weir J, Smith P. The development of a competency framework for pharmacists providing cancer services. J Oncol Pharm Pract. 2011:17(3):168-78.

39. Jones SC, Fleming G, Hay D, Ibrahim M, Pettit M, Wright E, et al. Development and piloting of a competency framework for pharmacy educational and practice supervisors. Pharm Educ. 2012;12(1):14-9.

40. Maitreemit P, Pongcharoensuk P, Kapol N, Armstrong EP. Pharmacist perceptions of new competency standards. Pharm Pract. 2008;6(3):113-20.

41. Kennie-Kaulbach N, Farrell B, Ward N, Johnston S, Gubbels A, Eguale T, et al, Pharmacist provision of primary health care: a modified Delphi validation of pharmacists' competencies. BMC Fam Pract. 2012;13(1):1-9.

42. Atkinson J, Paepe KD, Pozo AS, Rekkas D, Volmer D, Hirvonen J, et al. The PHAR-QA project: quality assurance in European pharmacy education and training. Results of the European network Delphi round 1: PHAR-QA Newsletter. PHARMINE; 2015. p. 1-31.

43. Adje DU, Oli AN. Community pharmacy in Warri, Nigeria: a survey of practice details. Sch Acad J Pharm SAJP. 2013;2(5):391-7.

44. Machula MC. Effect of trade liberalisation on community pharmacy in Zambia: a case study of the Copperbelt region [Internet] [MBA Thesis]. [Zambia]: The Copperbelt Uinversity School of Business Postgraduate Studies; 2007. Available from: http://dspace.cbu.ac.zm:8080/jspui/bitstream/ 123456789/127/1/MACHULA\%2C\%20C.\%20MOSES0001\%20-\%20Eff ect\%20of\%20trade\%20liberalisation\%20on\%20community\%20pharmacy. $\% 20 \mathrm{~A} \% 20$ case $\% 20$ study\%20of\%20The\%20Copperbelt\%20University.PDF. Accessed Mar 2018.

45. Terzibanjan A-R, Laaksonen R, Weiss M, Airaksinen M, Wuliji T. Medication error reporting systems-lessons learnt. Executive summary of the findings [Internet]. International Pharmaceutical Federation; 2008 [cited 2017 Oct 12]. Available from: http://www.fip.org/files/fip/Patient\%20Safety/Medication\%20 Error\%20Reporting\%20-\%20Lessons\%20Learnt2008.pdf.

46. Chukwuneke F. Medical incidents in developing countries: a few case studies from Nigeria. Niger J Clin Pract. 2015;18(7):20-4.

47. Walker EE. Strategies to reduce medication errors (II): Pharmaceutical Society of Ghana; 2016. Available from: https://psgh.site-ym.com/page/ V5N3_medicationerror/Strategies-to-reduce-medication-errors-ll.htm. Accessed Mar 2018

48. Kassi M. Pharmacy in Africa [Internet]. The Ohio State University School of Pharmacy; 2016 [cited 2017 Oct 12]. Available from: http://pharmacy.osu. edu/sites/default/files/forms/outreach/intro2pharm/global-practices/ Pharmacy-in-Africa_Kassi.pdf.

49. Wilson RM, Michel P, Olsen S, Gibberd RW, Vincent C, El-Assady R, et al. Patient safety in developing countries: retrospective estimation of scale and nature of harm to patients in hospitals. Br Med J. 2012;13:344.

50. Llewellyn RL, Gordon PC, Reed AR. Drug administration errors: time for national action. SAMJ South Afr Med J. 2011;101:319-20.

51. Scheele F, Teunissen P, Luijk SV, Heineman E, Fluit L, Mulder H, et al. Introducing competency-based postgraduate medical education in the Netherlands. Med Teach. 2008;30(3):248-53.

52. Danish Health and Medicines Authority. The seven roles of physicians [Internet]. Danish Health and Medicines Authority; 2014 [cited 2017 Jan 13]. Available from: https://www.sst.dk/en/news/2013/ /media/ 39D3E216BCBF4A9096B286EE44F03691.ashx.

53. Ringsted C, Hansen TL, Davis D, Scherpbier A. Are some of the challenging aspects of the CanMEDS roles valid outside Canada? Med Educ. 2006:40(8):807-15.

54. The Royal Australian and New Zealand College of Psychiatrists. Fellowship statements and competencies [Internet]. Melbourne, Australia: The Royal Australian and New Zealand College of Psychiatrists; 2012 [cited 2017 Jan 13] p. 3. Available from: https://www.ranzcp.org/Files/PreFellowship/2012Fellowship-Program/Fellowship-Competencies.aspx. 
55. Atkinson J, Rombaut B, Pozo AS, Rekkas D, Veski P, Hirvonen J, et al. Production of a framework of competences for pharmacy practice in the European Union. Pharmacy. 2014;2(2):161-74.

56. International Pharmaceutical Federation. Continuing professional development and continuing education in pharmacy: a global report [Internet]. The Haque, Netherlands: International Pharmaceutical Federation; 2014 p. 44. Available from: http://www.fip.org/files/fip/PharmacyEducation/ CPD_CE_report/FIP_2014_Global_Report_CPD_CE_online_version.pdf. Accessed Mar 2018.

57. Duwiejua M, Danquah DA, Andrews-Annan E. Assessment of human resources for pharmaceutical services in Ghana [Internet]. Pharmacy Council of Ghana, Ministry of Health, Ghana; 2009 [cited 2017 Jun 17]. Available from: assessment of human resources for pharmaceutical serviecs in ghana.

58. Gebretekle GB, Fenta TG. Assessment of pharmacists workforce in Ethiopia. Ethiop J Health Dev. 2013:27(2):1-10.

59. Abuturkey DHY. Assessment of human resources at the pharmaceutical sector [Internet]. The Republic of the Sudan Federal Ministry of Health, Directorate General of Pharmacy; 2012. Available from: https:/www.hrhresourcecenter. org/node/5018.html. Accessed Mar 2018.

60. Edwards P, Roberts I, Sandercock P, Frost C. Follow-up by mail in clinical trials does questionnaire length matter? Control Clin Trials. 2004;25(1):31-52.

61. Iglesias C, Torgerson D. Does length of questionnaire matter? A randomised trial of response rates to a mailed questionnaire. J Health Serv Res Policy. 2000:5(4):291-21.

62. Bowling A. Research methods in health: investigating health and health services. 3rd ed. Berkshire: Open University Press; 2009. p. 525.

63. de Vaus D. Surveys in social research [Internet]. 5th ed. Taylor \& Francis; 2002. 379 p. Available from: http://books.google.co.uk/books?id=11RDJEtBg48C Accessed Mar 2018

64. Abosse Akue-Kpakpo, editor. Study on international internet connectivity in sub-Saharan Africa. A report of the Regulatory and Market Environment Division (RME) of the Telecommunication Development Bureau and ITU-T Study Group 3 [Internet]. International Telecommunication Union, Geneva, Switzerland; 2013 [cited 2017 Oct 12]. Available from: https://www.itu.int/ en/ITU-D/Regulatory-Market/Documents/IIC_Africa_Final-en.pdf.

65. de Heer-Menlah FK. Internet access for African countries. Ubiquity. 2002;(4). Article No. 4. https://ubiquity.acm.org/article.cfm?id=763949. Accessed Mar 2018.

66. Olsen R. Self-selection bias. In: Lavrakas PJ, editor. Encyclopedia of survey research methods. Thousand Oaks: SAGE Publications, Inc;; 2008. p. 809-11.

\section{Submit your next manuscript to BioMed Central and we will help you at every step:}

- We accept pre-submission inquiries

- Our selector tool helps you to find the most relevant journal

- We provide round the clock customer support

- Convenient online submission

- Thorough peer review

- Inclusion in PubMed and all major indexing services

- Maximum visibility for your research

Submit your manuscript at www.biomedcentral.com/submit

) Biomed Central 